\title{
The Moderating Effect of Social Environment on the Relationship between Entrepreneurial Orientation and Entrepreneurial Intentions of Female Students at Nigerian Universities
}

\author{
Isidore Ekpe, \\ Norsiah Mat \\ College of Business, Universiti Utara Malaysia \\ 06010 Sintok, Kedah, Malaysia
}

\begin{abstract}
The objective of this study was to examine the moderating effect of social environment on the relationship between entrepreneurial orientation and entrepreneurial intentions of undergraduate female students of Nigerian Universities. Female students were chosen because they are more susceptible to social pressures. One of the hypotheses was to test whether social environment moderates the effect of entrepreneurial orientation on entrepreneurial intentions. A quantitative research method (survey) was used to solicit responses from 120 final year undergraduate female students of three University Business Schools in the North, East and West regions of Nigeria. This method was used because Universities in Nigeria offer similar courses and the respondents, according to previous studies in other contexts, show a higher propensity to firm formation. Data were analyzed using descriptive statistics and hierarchical regression. The results indicated that entrepreneurial orientation (self-efficacy and education) had significant positive influence on entrepreneurial intention among female business students in Nigeria. It was also found that social environment (friends' agreement) moderated the relationship between entrepreneurial orientation (education) and entrepreneurial intentions among the students. Again, the study contributed to the scant literature on entrepreneurial intentions among people in developing countries especially Nigeria. Therefore, the government should focus on ways to encourage entrepreneurship awareness among university students in Nigeria to enhance entrepreneurial intentions and self-employment. The study was limited to female students. Future studies could compare the entrepreneurial intentions of male and female students.
\end{abstract}

Keywords: Entrepreneurial orientation, social environment, entrepreneurial intentions 


\subsection{Introduction}

The relationship between entrepreneurial orientation and entrepreneurial intentions is widely discussed in the literature; and the debate as to whether entrepreneurship education leads to intention to start business is inconclusive. While some studies (for example Gatewood, Brush, Carter, Green \& Hart, 2004; Stohmeyer, 2007) found that entrepreneurship education was positively related to entrepreneurial intention and self-employment, other studies (for example Abdullah, Osman \& Rahim, 2009; Ying, 2008) discovered the contrary. However, limited attention has been paid to the social environment that may enhance or hinder entrepreneurial intentions. This is the focus of this study.

The Universities in Nigeria were established to produce skilled labour for the industries, government and for self-employment that would invariable lead to economic growth of the country. Unfortunately, course contents were not designed to emphasise self-employment. It is of recent, due to persistent youth unemployment in the country, that Entrepreneurship Development Programs (EDP) were introduced into the course contents of every Department of the Universities and other tertiary educational institutions to inculcate entrepreneurial orientation, interest and intentions in the students for possible self-employment after graduation.

The issues at stake are that most students in Nigeria, who have received entrepreneurial education, do not mature their entrepreneurial intentions into self-employment due to lack of practical entrepreneurial experience or exposure, occasioned by misdirected course contents of the institutions concerned. The situation is similar in other developing countries. For example, Abdullah et al. (2009) found that students could not translate their acquired education or skills into self-employment because less emphasis was placed on trainee characteristics, training environment and University-Industrial linkages. Business students who are exposed to entrepreneurial education for self-employment could be called academic entrepreneurs.

The future of the female academic entrepreneurs, in particular, becomes worrisome due to gender-related discriminations prevalent in developing countries, Nigeria inclusive (May, 2007; Otero, 1999; Roomi \& Parrot, 2008). They are also mostly affected by poverty and unemployment than their male counterparts (Maduagwu, 2000; Mohd \& Hassan, 2008; Porter \& Nagarajan, 2005). Moreover, they lack interest in discussing entrepreneurship issues with their family and friends, in addition to their lack of self-confidence. Whereas the search for, discovery and utilisation of opportunity for self-employment requires a positive attitude to risk (Shane, 2003).

Poor social environment is another bane of these future entrepreneurs. The society looks down on entrepreneurship compared with paid jobs upon graduation. Poor perceptions mostly come from social networks such as friends, family members, role models and advisors 
(Mayer, Hackler \& McFarland, 2007) and this hinders entrepreneurial orientation from maturing into entrepreneurial intentions.

Though it is stated that intentions are the best predictors of behaviour and that entrepreneurial intentions are the central point in understanding entrepreneurial process (Kruger, 2004); the question is: does entrepreneurial orientation lead to entrepreneurial intention without the influence of the social environment? Therefore this study, which is limited to the undergraduate female students of Nigerian Universities, is aimed at investigating the moderating effect of social environment on the relationship between entrepreneurial orientation and entrepreneurial intentions of the students.

\subsection{Literature Review}

\subsection{Entrepreneurial intention}

The issues relating to entrepreneurial interest and intention to start business have been handled by previous studies; prominent among which is Ajzen (1991)' Theory of Planned Behaviour. As such, this study is underpinned on the Theory of Planned Behaviour (Ajzen, 1991). This theory is normally used to explain human behaviour which consists of attitude towards behaviour, subjective norm and perceived behavioural control. Attitude towards behaviour means the degree to which an individual has a favourable or unfavourable evaluation of behaviour, subjective norm is the perceived social pressures to perform or not to perform the behaviour, and perceived behavioural control refers to the perceived ease or difficulty of performing the behaviour. The theory states that intentions are the best predictors of behaviour; as such entrepreneurial intentions become the central point in understanding entrepreneurial process (Kruger, 2004). The performance of a particular behaviour also depends on other non-motivational factors such as availability of opportunities and resources like money, time, skills and cooperation of other people. This represents actual control over the behaviour. That is, the performance of behaviour is a joint function of intention and perceived behavioural control (Ajzen, 1991). Therefore, entrepreneurial intentions model is employed to investigate the moderating effect of social environment on the relationship between entrepreneurial orientation and entrepreneurial intention.

\subsection{Entrepreneurial orientation}

This concerns the entrepreneur's reasons for entrepreneurial decision, background information (for example education, work experience or training) and his/her personality (for example self-efficacy expressed as attitude or ability and self-confidence). It is a decisionmaking process measured by an individual's risk propensity (Shane, 2003).

\section{Reasons for Entrepreneurial Decision:}


These are often regarded as the pull factors in entrepreneurial activity (Hisrich, Peters \& Shepherd, 2008; Kuzilwa, 2005; North, 1990). The need for achievement and autonomy, risktaking, control of business and self-efficacy are vital characteristics for entrepreneurial intentions (Shane, 2003). Demography, skills and reputation are also important to successful entrepreneurs (Carter \& Shaw, 2006; Gatewood et al; 2004). Other characteristics of entrepreneurial intentions include: strong desire for independence, innovation, risk-taking, resourcefulness, business skills, knowledge, and networks (Salman, 2009). Business knowledge includes knowledge of top players in the industry, knowledge of product range and market trends. Business skills include technical and managerial skills which could be acquired through training, seminars and workshops. Experience could be acquired through formal education and business knowledge (Salman, 2009). Innovation and decision-making ability are other characteristics (Cunha, 2007). Ambition, self-confidence and high level of energy have also been recognized as vital entrepreneurial characteristics (Idris \& Mahmood, 2003). Having the right motive of venturing into business has been found to be one of the characteristics of successful entrepreneurs. The right motive should be the first determinant before entering into business (Mitchell, 2004; Porter \& Nagarajan, 2005; Shane, 2003). Selfevaluation and intuition are also crucial characteristics (Shane, 2003).

Educational background: In this context, education is the training that students received in entrepreneurship. It is reported that entrepreneurs in high-income countries are better educated than those in low income countries (Ibru, 2009). Literature confirmed that skill training and tertiary education has positive relationship with entrepreneurs' performance, especially women (Akanji, 2006; Cheston \& Kuhn, 2002; Kuzilwa, 2005). Many entrepreneurs in developing countries lack this especially women (Ibru, 2009), whereas the exploitation of entrepreneurial opportunity depends on the entrepreneur's level of education, skills or knowledge acquired through work experience, social network and credit (Shane, 2003). It has been suggested that classroom theoretical knowledge should be supported with practical business education through internships in small business firms (Robinson \& Malach, 2004; Ying, 2008). Similarly; Lans, Hulsink, Baert and Mulder (2008) suggested that entrepreneurial competence could be acquired through proper education, training and work experience.

Work Experience/Training: This is the knowledge or skill gained in a particular job over time. It is reported that entrepreneurs in developing countries lack business experience due to lack of former paid employment especially women, whereas literature asserted that business experience is one of the vital entrepreneurial characteristics (Antoncic, 2006), and evidences support the fact that a minimum of three years business experience is sufficient to assess an entrepreneur (Antoncic, 2006; Carter \& Shaw, 2006; Harrison and Mason, 2007; Kuzilwa, 2005; Salman, 2009). Most entrepreneurs in developing countries lack training especially women (Brana, 2008; IFC, 2007) and entrepreneurial process is a vital source of developing 
human capital as well as plays a crucial role in providing learning opportunity for individuals to improve their skills, attitudes and abilities (Brana, 2008; Cheston \& Kuhn, 2002; Shane, 2003). Again, due to poverty and low educational levels in developing countries (Porter \& Nagarajan, 2005; Roomi \& Parrot, 2008); training is very necessary for entrepreneurs as it could provide the skills and experience needed for business (Akanji, 2006; Cheston \& Kuhn, 2002; Kuzilwa, 2005).

Self efficacy: This portrays an entrepreneur's personality in terms of his/her attitude or ability, readiness and self-confidence to face risk in entrepreneurial venture because entrepreneurship is about risk-taking (Shane, 2003). As discussed in the early part of this literature, attitude towards behaviour means the degree to which an individual has a favourable or unfavourable evaluation of the behaviour (Ajzen, 1991). For entrepreneurial intentions to be translated into self-employment, it depends on the entrepreneur's personality and abilities (Majumdar, 2008). Studies, such as Crisp and Turner (2007), found that attitude and behavioural intentions are positively related; and attitude towards behaviour leads to intention which eventually leads to actual behaviour (Ajzen, 1991). Self-confidence is also related to entrepreneurial behaviour. For example, self-confidence was found to have a moderating influence on the relationship between loan access, entrepreneurial opportunity and women entrepreneurs' sales performance in Nigeria (Ekpe, 2011). Therefore, this study hypothesized that:

Hypothesis 1: Entrepreneurial orientation (education, self-efficacy, entrepreneurial decision, work experience) is positively related to entrepreneurial intentions.

\subsection{Social Environment (Social influence):}

This involves the social ties, the influence of friends and family, role models and advisors. Social networks provide access to information and resources necessary for entrepreneurial activity (Tata \& Prasad, 2008). Society's perception about, and attitude towards, entrepreneurship is poor (Mayer et al., 2007); whereas social networks was found to be positively related to entrepreneurial opportunity or self-employment in USA, UK and Nigeria respectively (Allen, 2000; Carter \& Shaw, 2006; Ekpe et al., 2011; Lawal, Omonona, Ajani \& Oni, 2009; Shane, 2003). Perceived social environment also had positive impact on students' entrepreneurial intentions in China (Yun \& Yuan-qiong, 2010). A weak relation was found to exist between social norms and entrepreneurial intention, indicating that social environment affect individual's attitude to entrepreneurial intention (Ajzen, 1991; Krueger, 2000).

On the other hand, Vob and Muller (2009) concluded that entrepreneur's behaviour towards entrepreneurial activity is influenced by a set of factors such as personality in form of attitude, resources and environment. Other studies such as Kuzilwa (2005), Shastri and Sinha (2010), 
concluded that the possession of education, right attitude to risk, motivation and working experience aside; social environment may hinder identification and exploitation of entrepreneurial opportunity. Nasurdin, Ahmad and Lin (2009) found that social identity (appreciation from family, friends and society if someone becomes an entrepreneur) did not have any significant relationship with entrepreneurial intentions in Malaysia.

The inconsistency in these studies suggest the need for a moderator because Baron and Kenny (1986) suggested that when there is inconsistent or weak relation between predictor and criterion variables, then a moderator is necessary. Therefore, the study hypothesized that:

H2: Social environment (influence of friends, families, role models, advisors) moderates the relationship between entrepreneurial orientation and entrepreneurial intentions.

In summary, previous studies that measured the direct relationship between entrepreneurial orientation and entrepreneurial intentions have established inconsistent results. With the indirect measurement, Yun and Yuan-qiong (2010) measured perceived social environment and entrepreneurial intention, mediated with entrepreneurial self-efficacy, and found a significant mediating influence in China. Nasurdin, Ahmad and Lin (2009) studied a model of entrepreneurial intention, mediated with perceived desirability, and found insignificant mediating influence in Malaysia. Enkhbold-Chuluunbaatar and Kung (2011) measured entrepreneurial intention and entrepreneurial behaviour, moderated with social capital, and found significant moderating influence in Taiwan.

Therefore, limited study is available on the moderating effect of social environment on the relationship between entrepreneurial orientation and entrepreneurial intention. This is the focus of this study as it tries to fill this gap.

\subsection{Methodology}

\subsection{Survey Procedures}

A quantitative research method (survey) was employed to collect data from 144 final year undergraduate female students of three University Business Schools in Nigeria. However, after data cleaning, data for 120 students were used for the analysis. Female students were chosen because they are more susceptible to social pressures. The population was also chosen because Universities in Nigeria offer similar courses. There are 96 Universities in Nigeria as at 2009 (Ajadi, 2010). This is made up of 27 Federal Universities, 35 State Universities and 34 Private Universities. From this list, three Universities were chosen: one each from the north, east and west regions of Nigeria. The population of this study was 144 final year female business students in the three Universities for 2010/2011 academic session. Total 
sampling method was adopted, due to the small size of the population. Data were analysed using descriptive statistics and hierarchical regression.

\subsection{Measures}

Entrepreneurial orientation was measured in terms of educational background or training and self-efficacy. These measures were adapted from Sriprasert (2007). Social environment was measured in terms of social influence (influence of friends, families, role models and advisors), and the measures were adapted from Kennedy et al. (2003). Measures for entrepreneurial intentions were also adapted from Kennedy et al. (2003). All the measures were tapped on a 4-point scale.

The conceptual framework for this study is shown in Figure 1

** [Insert Figure 1 about here]

The moderator-interaction effects were determined in line with the procedure suggested by Baron and Kenny (1986). A moderator-interaction effect would occur if a relation is substantially reduced instead of being reversed (Baron \& Kenny, 1986). Again, a moderator hypothesis is supported if the interaction or the product of a predictor variable and the moderator is significant when the predictor and the moderator were being controlled (Baron \& Kenny, 1986).

\subsection{Results}

\subsection{Data cleaning}

The data used were free from errors. For instance, negatively worded questions reverse coded, outliers were detected by comparing the Mahalanobis distance $\left(\mathrm{D}^{2}\right)$ or chi-square value of each respondent with the critical or table chi-square value, using the number of predictor variables as the degrees of freedom, at $p<0.001$ (Hair et al., 2010). Extreme observations in a sufficient number of variables in multivariate and univariate detections were deleted (Hair et al., 2010). Normality was handled through skewness and kurtosis. Observations with Z-score above or below the critical value of 1.96 , at $\mathrm{p}=0.05$ were deleted (Hair et al., 2010).

Linearity was detected through Pearson correlation matrix and all predictors correlated with the criterion variable. The output of the hierarchical regression analysis indicated that the error term (as indicated by Durbin Watson statistics) were all within the recommended range of 1.50-2.50. There was no case of multicollinearity as the collinearity statistics of the regression output indicated Tolerance $>0.10$, Variance Inflationary Factor $<10$ and Condition index $<30$ in most cases (Hair et al., 2010). Homoscedasticity (equality of variance) was 
verified through an examination of the residuals of the regression output which showed no clear relationship between the residual and the predicted values (Coakes \& Steed, 2003).

\subsection{Goodness of measures}

The principal component analysis for the predictor variables revealed the presence of two components with eigenvalues greater than one, using Varimax with Kaiser's normalization rotation method. These two components factors were renamed self-efficacy and education. The naming was done according to the items with the highest factor loadings in each component. The two components explained a total variance of $56.0 \%$. Communalities were above 0.6 for most variables, anti-image (MSA) was above 0.5 for each item and Barlett's test of sphericity (sig.) was 0.000 which was $<0.05$. Kaiser-Meyer-Olkin' measure of sampling adequacy was 0.658 and factor loadings were above 0.5 as suggested by Hair et al. (2010). The moderator, social environment, converged into one component renamed friends' influence (agreement); with a total variance explained as $57.2 \%$. Communalities were above 0.6 for most items, MSA was also above 0.5 and Barlett's test of sphericity (sig.) was 0.000 . Factor loadings were above 0.5 and KMO was 0.751 . The criterion variable converged into one component with a total variance explained of $62.0 \%$. Communalities were above 0.6 for most items, MSA was above 0.5 and Barlett's test of sphericity (sig.) was 0.000 . Factor loadings were above 0.5 and KMO was 0.600 .

After the principal component factor analysis, the data were standardized by finding the mean of items of each factor or construct which then became the variables for subsequent analyses such as reliability. However, for hierarchical regression, the variables were centralized to avoid high multicollinearity (Aiken \& West, 1991). Prior to hierarchical multiple regression, the independent variables were multiplied with the moderator to get the product of interaction terms that were entered into specific levels of the hierarchical regression analysis.

Reliability test was performed on the factors after the exploratory factor analysis. Selfefficacy had Cronbach's alpha of 0.70 and education had alpha of 0.63. Alpha for friends' influence (agreement) was 0.84 and alpha for entrepreneurial intention was 0.71 .

*insert Table 1 about here*

Table 1 above provided a summary of the descriptive statistics of the variables. It indicated that among the independent variables, self-efficacy had a higher mean value (3.32) and standard deviation (0.45). This proved that female students who are future entrepreneurs perceived self-efficacy as having more influence on their entrepreneurial intentions than 
education which had a mean value of 2.83 and standard deviation of 0.59 . The age statistics showed that the majority (82.5\%) of the respondents were in the age bracket of 20-30years.

*insert Table 2 about here*

Beta 1 (step 1) showed the direct influence of entrepreneurial orientation (self-efficacy and education) on entrepreneurial intentions. The $\mathrm{R}$ square was 0.127 . In other words, the two independent variables explained $12.7 \%$ of the variance in entrepreneurial intentions ( $\mathrm{R}$ square change $=0.127, \mathrm{p}<0.001)$. The overall regression model was significant (Sig. $\mathrm{F}$ change $=$ $0.000, \mathrm{R}$ square $=0.127, \mathrm{~F}$ change $=8.522, \mathrm{p}<0.001)$. From the individual coefficients, only self-efficacy (beta $=-0.349, \mathrm{p}<0.001$ ) was significant. This indicated that self-efficacy was a critical factor to the female students' entrepreneurial intentions. In beta 2 (step 2), when friends' influence (agreement) was entered, the $\mathrm{R}$ square was 0.348 . This showed that total variance explained by the model as a whole became $34.8 \%$ ( $\mathrm{R}$ square $=0.348, \mathrm{~F}$ change $=$ $39.363, \mathrm{p}<0.001)$. The additional variable explained an additional $22.1 \%$ of the variance in entrepreneurial intentions, after controlling self-efficacy and education (R square change = 0.221 ). Again, the overall model was significant (Sig. F change $=0.000, \mathrm{p}<0.001$ ). In beta 3 (step 3), when the interaction was performed, then $\mathrm{R}$ square became 0.375 . This showed the total variance explained by the model as a whole was $37.5 \%$. The interaction effect was noticed by the increase in $\mathrm{R}$ square value by $2.7 \%(\mathrm{R}$ square change $=0.027)$ which explained an additional $2.7 \%$ of the variance in entrepreneurial intentions ( $\mathrm{R}$ square $=0.375, \mathrm{~F}$ change $=$ $2.482, \mathrm{p}<0.10$ ). The overall model was significant (Sig. F change $=0.088, \mathrm{p}<0.10$ ).

Hypothesis 1 predicted a positive relationship between entrepreneurial orientation (education, self-efficacy) and entrepreneurial intentions. The regression analysis result, Table 2 (step 1) revealed that only self-efficacy (beta $=-0.349, \mathrm{p}<.001$ ) had significant relationship with entrepreneurial intentions. Education (beta $=0.096, \mathrm{p}<.001$ ) was insignificant. Thus, hypothesis 1 was partially supported. Hypothesis 2 examines the moderating influence of social environment (influence of friends, families, role models, advisors) on the relationship between entrepreneurial orientation (self-efficacy and education) and entrepreneurial intentions. As shown in Table 2 (step 3), friends' influence interacted with education (beta = $0.169, \mathrm{p}<.10)$ to predict entrepreneurial intentions. The interaction of friends' influence with self-efficacy was insignificant. The regression coefficient for friends' influence (moderator) was significant which indicated the existence of a quasi moderator (Sharma, 2003). Thus, hypothesis 2 was partially supported. The significant beta coefficient for the interaction term (beta $=0.169, \mathrm{p}<.10$ ) indicated that the impact of education on entrepreneurial intentions differ by the degree of emphasis on friends' influence on the part of the female students. 


\subsection{Discussion}

The current findings support previous studies that entrepreneurial orientation, in terms of selfefficacy, skill acquisition training and education, are positively related to entrepreneurial intentions (Ajzen, 1991; Carter \& Shaw, 2006; Gatewood et al; 2004; Shane, 2003). Though this study fails to support the direct relationship between education and entrepreneurial intentions (Ibru, 2009; Salman, 2009); however collectively, the overall model was significant which indicated that entrepreneurial orientation (self-efficacy and education) are positively related to entrepreneurial intentions of the female students of Nigerian Universities. This could possibly be because without self-efficacy, education in itself could not lead to entrepreneurial intentions of the female students. The interaction of friends' influence with education was significant, indicating that social environment moderated the relationship between entrepreneurial orientation and entrepreneurial intentions of the female students. In other words, entrepreneurial orientation (education) could only lead to entrepreneurial intentions of the female students if their friends agree or support the idea. This is an interesting discovery and a novel contribution of this study to the theory of entrepreneurship.

\subsection{Conclusion}

The results of these analyses confirm that the overall model of self-efficacy and education was significant but self-efficacy had the greater influence on entrepreneurial intentions of the female students of Nigerian Universities. This indicated that entrepreneurial orientation is positively related to entrepreneurial intentions of the female students. The interaction of friends' influence with education was significant, indicating that social environment moderated the relationship between entrepreneurial orientation and entrepreneurial intentions of the female students. This study recommends that female business students should cultivate self-efficacy in their abilities as future entrepreneurs and should not allow their friends to discourage their entrepreneurial intentions. The government should involve youth graduates in her entrepreneurship development programs, provide more entrepreneurship awareness among undergraduate students in Nigeria, as well as provide more funding and other support services to entrepreneurs so as to encourage the undergraduate youths as future entrepreneurs.

\section{References}

Abdullah, S. H., Osman, M. H., \& Rahim, M. S. H. (2009). The key concept of academic technology entrepreneurship in the current practice. Asia Pacific Journal of Innovation and Entrepreneurship, Korea Business Incubation Association , 2 (1), 77 96.

Aiken, L. S. \& West, S. G. (1991). Multiple regression: Testing and interpreting interactions. Newbury Park, London: Sage. 
11 I P a g e International Journal of Management Sciences and Business Research, 2012, Vol. 1, No. 4 (ISSN: 2226-8235)

Ajadi, T. O. (2010). Private Universities in Nigeria-the challenges ahead. American Journal

Scientific Research , 7, 15-24.

Ajzen, I. (1991). The Theory of Planned Behavior. The Organizational Behavior and Human Decision Processes , 50, 179-211.

Akanji, O. O. (2006). Microfinance as a strategy for poverty reduction. Central Bank of Nigeria Economic and Financial Review, 39 (4).

Allen, D. W. (2000). Social networks and self-employment. Journal of Socio-Economics , 29 (1), 487501.

Antoncic, B. (2006). Impacts of diversification and corporate entrepreneurship strategy making on growth and profitability: A normative model. Journal of Enterprising Culture , 14 (1), 49-63.

Baron, R. M. \& Kenny, D. A. (1986). The moderator-mediator variable distinction in social psychology research: Conceptual, strategic, and statistical considerations. Journal of Personality and Social Psychology, 51 (6), 1173-1182.

Brana, S. (2008). Microcredit in France: Does gender matter? $5^{\text {th }}$ Annual Conference-Nice. European Microfinance Network.

Carter, S. \& Shaw, E. (2006). Women's business ownership: Recent research and policy developments. UK: Small Business Service.

Cheston, S. \& Kuhn, L. (2002). Empowering women through microfinance. A case study of Sinapi Aba Trust, Ghana. USA: Opportunity International.

Coakes, S. J. \& Steed, L. G. 2003. SPSS: Analysis without anguish, version 11.0 for windows. Singapore: Kyodo.

Crisp, R. J. \& Turner, R. N. (2007). Essential Social Psychology. London: SAGE Publication.

Cunha, M. P. (2007). Entrepreneurship as decision-making: Rational, intuitive and improvisational approaches. Journal of Enterprising Culture , 15 (1), 1-20.

Ekpe, I. (2011). Women entrepreneurs' performance: Microfinance factors with mediating $\quad$ effect of opportunity and moderating effect of attitude. Malaysia: PhD Thesis, OYA Graduate School of Business, Universiti Utara Malaysia.

Ekpe, I., Mat, N. \& Razak, R. C. (2011). Attributes, environment factors and women entrepreneurial activity: A literature review. Asian Social Science , 7 (9), 124-130.

The Moderating Effect of Social Environment on the Relationship between Entrepreneurial Orientation and Entrepreneurial Intentions of Female Students at Nigerian Universities 
12 | P a g e International Journal of Management Sciences and Business Research, 2012, Vol. 1, No. 4 (ISSN: 2226-8235)

Enkhbold-Chuluunbaatar, O. D. \& Kung, S. (2011). The entrepreneurial start-up process: The role of social capital and the social economic condition. Asian Academy of Management Journal , $16(1), 43-71$.

Gatewood, E. J., Brush, C. G., Carter, N. M., Greene, P. G. \& Hart, M. M. (2004). Women entrepreneurs, growth and implications for the classroom. USA: Coleman Foundation whitepaper series for the USA Association for Small Business and Entrepreneurship.

Hair, J. F., Black, W. C., Babin, B. J. and Anderson, R. E. 2010. Multivariate data analysis, a global perspective ( $7^{\text {th }}$ ed.). New Jersey, USA: Pearson Education Inc.

Harrison, R. T. \& Mason, C. M. (2007). Does gender matter? Women business angels and the supply of entrepreneurial finance. Entrepreneurship Theory and Practice, 31 (3), 445-472.

Hisrich, R. D., Peters, M. P. \& Shepherd, D. A. (2008). Entrepreneurship (7th ed.). New York: McGrawHill Co. Inc.

Ibru, C. (2009). Growing microfinance through new technologies. Federal University of Technology, Akure, Nigeria.

Idris, A. M. M. \& Mahmood, R. (2003). Bank managers' perceptions of the characteristics of successful entrepreneurs. Retrieved August 25, 2009, from Malaysian Management Review, 38 (1): http://www.mgv.mim.edu.my/MMR/0306/frame.htm

International Finance Corporation (IFC). (2007). Gender entrepreneurship markets, GEM country brief. Afghanistan: GEM.

Kennedy, J., Drennan, J., Renfrow, P. \& Watson, B. (2003). Situational factors and entrepreneurship. A paper presented at the 16th Annual Conference (28 September-1 October, 2003). Ballarat, Australia: Small Enterprise Association of Australia and New

Zealand.

Krueger, N., Reilly, M. D. \& Carsrud, A. L. (2000). Competing models of entrepreneurial intentions. Journal of Business Venturing , 15, 411-432.

Kruger, M. E. (2004). Creativity in the entrepreneurial domain. University of Pretoria: Faculty of Economics and Management Sciences.

Kuzilwa, J. (2005). The role of credit for small business success: A study of the National Entrepreneurship Development Fund in Tanzania. The Journal of Entrepreneurship , 14 (2), 131-161.

The Moderating Effect of Social Environment on the Relationship between Entrepreneurial Orientation and Entrepreneurial Intentions of Female Students at Nigerian Universities 
13 I P a g e International Journal of Management Sciences and Business Research, 2012, Vol. 1, No. 4 (ISSN: 2226-8235)

Lans, T., Hulsink, W., Baert, H. \& Mulder, M. (2008). Entrepreneurship education and training in a small business context: Insights from the competence-based approach. Journal of Enterprising Culture, 16 (4), 363-383.

Lawal, J. O., Omonona, B. T., Ajani, O. I. Y., \& Oni, O. A. (2009). Effects of social capital on credit access among cocoa farming households in Osun State, Nigeria. Agricultural Journal , 4 (4), 184-191.

Maduagwu, A. (2000). Alleviating poverty in Nigeria, the Economics of rural poverty in Nigeria. Retrieved January 23, 2009, from http://www.afbis.com/analysis/alleviating_poverty.htm

Majumdar, S. (2008). Modelling growth strategy in small entrepreneurial business organizations. The Journal of Entrepreneurship, 17 (2), 157-168.

May, N. (2007). Gender responsive entrepreneurial economy of Nigeria: Enabling women in a disabling environment. Journal of International Women's Studies , 9 (1), 167-175.

Mayer, H., Hackler, D. \& McFarland, C. (2007). Skills, capital and connections, too: A regional social environment perspective of women entrepreneurs. Canadian Journal of Regional Science , 30 (3), 411-432.

Mitchell, B. C. (2004). Motives of entrepreneurs: A case study of South Africa. Journal of Entrepreneurship, 13 (1), 168-183.

Mohd, D. A. \& Hassan, Z. (2008). Microfinance in Nigeria and the prospect of introducing its Islamic version there in the light of selected Muslim countries' experience. Retrieved January 26, 2009, from http://www.mpra.ub.uni-muenchen.de/8287/

Nasurdin, A. M., Ahmad, N. H. \& Lin, C. E. (2009). Examining a model of entrepreneurial intention among Malaysians using SEM procedure. European Journal of Scientific Research , 33 (2), 365373.

North, D. C. (1990). Institutions, institutional change and economic performance. Cambridge, UK: Cambridge University Press.

Otero, M. (1999). Bringing development back into microfinance. Latin America: ACCION International.

Porter, E. G. \& Nagarajan, K. V. (2005). Successful women entrepreneurs as pioneers: Results from a study conducted in Karaikudi, Tamil Nadu, India. Journal of Small Business and Entrepreneurship , 18 (1), 39-52.

Robinson, P. \& Malach, S. (2004). Multi-disciplinary entrepreneurship clinic: Experiential education in theory and practice. Journal of Small Business and Entrepreneurship , 17 (1), 317-331.

The Moderating Effect of Social Environment on the Relationship between Entrepreneurial Orientation and Entrepreneurial Intentions of Female Students at Nigerian Universities 
14 I P a g e International Journal of Management Sciences and Business Research, 2012, Vol. 1, No. 4 (ISSN: 2226-8235)

Roomi, M. A. \& Parrot, G. (2008). Barriers to development and progression of women entrepreneurs in Pakistan. The Journal of Entrepreneurship , 17 (1), 59-72.

Salman, A. (2009). How to start a business: A guide for women. Pakistan: Center for International Private Enterprise, Institute of National Endowment for Democracy, affiliate of the USA Chamber of Commerce.

Shane, S. (2003). A general theory of entrepreneurship: The individual-opportunity nexus. UK: Edward Elgar.

Sharma, N. (2003). The role of pure and quasi moderators in services: An empirical investigation of ongoing customer service-provider relationships. Journal of Retailing and Consumer Services , 10, 253-262.

Shastri, R. K. \& Sinha, A. (2010). The socio-cultural and economic effect on the development of women entrepreneurs (with special reference to India). Asian Journal of Business Management , 2 (2), 30-34.

Sriprasert, P. (2007). Entrepreneurial commitment among the members of the community based enterprises: A case study of OTOP scheme in southern Thailand. Malaysia: $\quad$ PhD Thesis, Centre for Graduate Studies, Universiti Utara Malaysia.

Stohmeyer, R. (2007). Gender gap and segregation in self-employment: On the role of field of study and apprenticeship training. Germany: German Council for Social and Economic Data (RatSWD).

Tata, J. \& Prasad, S. (2008). Social capital, collaborative exchange and microenterprise performance: The role of gender. International Journal of Entrepreneurship and Small Business , 5 (3/4), 373-385.

Vob, R. \& Muller, C. (2009). How are the conditions for high-tech start-ups in Germany. International Journal of Entrepreneurship and Small Business, 7 (3), 285-311.

Ying, L. Y. (2008). How industry experience could help in the teaching of entrepreneurship in Universities in Malaysia. Sunway Academic Journal , 5, 48-64.

Yun, C. \& Yuan-qiong. (2010). The impact of perceived social environment on students' entrepreneurial intentions: A Chinese perspective. A paper presented at the International Conference, 7-9 November 2010 (pp. 1-4). Henan: E-Product, E-Service and E-Entertainment (ICEEE).

Entrepreneurial orientation

Social environment

The Moderating Effect of Social Environment on the Relationship between Entrepreneurial Orientation and Entrepreneurial Intentions of Female Students at Nigerian Universities 
15 I P a g e International Journal of Management Sciences and Business Research, 2012, Vol. 1, No. 4 (ISSN: 2226-8235)

Entrepreneurial intention

Figure 1: The Conceptual Framework

Table 1

Descriptive Analysis of the Variables (Mean and Standard Deviation) and Cronbach' Alpha Coefficient

\begin{tabular}{|c|c|c|c|c|}
\hline Variable & Mean & Std. Deviation & $\begin{array}{l}\text { Cronbach' } \\
\text { alpha }\end{array}$ & $\mathrm{N}$ \\
\hline Self-efficacy (SEff) & 3.32 & 0.45 & 0.70 & 120 \\
\hline Education (Edu) & 2.83 & 0.59 & 0.63 & 120 \\
\hline $\begin{array}{l}\text { Friends' influence/agreement } \\
\text { (FInfl) }\end{array}$ & 1.73 & 0.62 & 0.84 & 120 \\
\hline $\begin{array}{l}\text { Entrepreneurial } \\
\text { (EntrInt) }\end{array}$ & 1.97 & 0.56 & 0.71 & 120 \\
\hline
\end{tabular}

Table 2

Results of Hierarchical Regression on Entrepreneurial Intentions

\begin{tabular}{llll}
\hline Variables & Beta 1 & Beta 2 & Beta 3 \\
& (Step 1) & (Step 2) & (Step 3) \\
\hline Independent Variables: & & & \\
Self-efficacy (SEff) & $-0.349 * * * *$ & $-0.200 * *$ & -0.144 \\
Education (Edu) & 0.096 & $0.160 * *$ & $0.275 * *$ \\
Moderator: & & & \\
Friends $\quad$ influence/agreement & & $0.498 * * * *$ & $0.470 * * * *$
\end{tabular}

The Moderating Effect of Social Environment on the Relationship between Entrepreneurial Orientation and Entrepreneurial Intentions of Female Students at Nigerian Universities 
16 | P a g e International Journal of Management Sciences and Business Research, 2012, Vol. 1, No.

(FInfl)

Interaction Term:

$\begin{array}{ll}\text { SEff*FInfl } & 0.126\end{array}$

$\begin{array}{ll}\text { Edu*FInfl } & 0.169^{*}\end{array}$

$\begin{array}{llll}\text { R Square } & 0.127 & 0.348 & 0.375\end{array}$

$\begin{array}{llll}\text { Adjusted R Square } & 0.112 & 0.331 & 0.348\end{array}$

$\begin{array}{llll}\text { R Square Change } & 0.127 & 0.221 & 0.027\end{array}$

$\begin{array}{llll}\text { F Value } & 8.522 & 39.363 & 2.481\end{array}$

$\begin{array}{llll}\text { Sig. F Change } & 0.000 & 0.000 & 0.088\end{array}$

Note: $* * * * \mathrm{p}<.001 ; * * * \mathrm{p}<.01 ; * * \mathrm{p}<.05 ; * \mathrm{p}<.10$

$\mathrm{DV}=$ Entrepreneurial Intentions

SEff $=$ Self-efficacy, Edu = Education, FInfl $=$ Friends' influence .

Publication reference:

International Journal of Management Sciences and Business Research Journal's profile at:

http://www.ijmsbr.com/

and submit your manuscripts online.

Dr. Johnkeets, USA

Chief Editor

International Journal of Management Sciences and Business Research

Head Office

61 Smedley Lane Cheetamhill Road

Manchester M8 8XG, England

Email: editor@ijmsbr.com or info@ijmsbr.com

The Moderating Effect of Social Environment on the Relationship between Entrepreneurial Orientation and

Entrepreneurial Intentions of Female Students at Nigerian Universities 